\title{
Mining Investment Legal Certainty Under The Terms of Act No. 4 Of 2009 Concerning Mineral and Coal Mining and Act No. 25 of 2007 on Investment
}

\author{
Suroto $^{1}$ and Gunarto ${ }^{2}$
}

\begin{abstract}
In this study the issues to be discussed in are: Mining Investment Legal Certainty According to provisions of Act No. 4 of 2009 on Mineral and Coal and Act No. 25 of 2007 on Investment. Based on the results of this study are Legality exploitation of minerals statutory number number 4 Legality exploitation of minerals statutory number number 4 of 2009 substantially only in a form that permit, in contrast to the legality of the concession at the time of the enactment of Act No. 1, 1967, consists of a wide variety of forms namely mining Authority (KP) contract of work (COW), mineral and agreements coal mining works (PKP2B) and SIPDs for extractive industry and artisanal mining licenses for artisanal mining. Various legality at the time of the enactment of Act No. 11 of 1967, led to the coordination, supervision and control of less than the maximum, because every legality issued to a mining business activity carried out not in a good coordination. Prior to the issuance of Act No. 25 of 2007 is still a very significant difference between foreign investors and domestic investors. This is evident from the provisions of legislation. Foreign investment is regulated in Act No. 1 of 1967 concerning Foreign Investment whereas domestic investment stipulated in Act No. 6 of 1968 on Domestic Investment.

Keywords: Rule of Law; Mining; Investment.
\end{abstract}

\section{Introduction}

Mining business is one area of business that gets top priority of the government before and after the issuance of the Investment Law, both for foreign and domestic parties. To that end, the government is trying to direct and manage the natural resources that are included in the mining business. Mining business include petroleum, natural gas, coal, metals, tin, nickel, bausit, sand iron, silver and copper concentrates. ${ }^{3}$ Management of mining rights is the right to master the state as stipulated in article 33 of the Constitution of 1945 (1945) paragraph (2) and (3) states that: Paragraph (2): production branches which are important for the country and dominate the life of people controlled by the state; Paragraph (3): earth and water and natural resources contained therein controlled by the state and used for the people's welfare.

Under the provisions of Article 33 UUD 1945 mentioned above it is clear that mining is one of the branches of production controlled by the state, in the sense that the authority of the management, allocation and utilization by the state for the welfare of the people of Indonesia.

Mining business development programs aimed at the provision of industrial raw materials in the country, the increase in exports and revenues, as well as the expansion of employment and business opportunities. Construction of mining business mainly

\footnotetext{
${ }^{1}$ Student of Masters (S2) of Law Faculty of Law Unissula Semarang e-mail: murodtop76@gmail.com

${ }^{2}$ Professor of Faculty of Law Unissula Semarang

${ }^{3}$ Amirudin Ilmar 2004 Hukum Penanaman Modal Di Indonesia Penerbit Prenada Media Jakarta p. 113
} 
through the diversification of mining and mining products in an efficient management. ${ }^{4}$ Previous mining business activities regulated under Act No. 11 of 1967 on Basic Provisions of Mining. This law states that mining operations can be executed by: government agencies; State enterprises; The local company; Companies with capital together countries and regions; Cooperative.

Act No. 4 of 2009 on Mineral and Coal Mining is a new law that replaces the Act longer namely Act No. 11 of 1967 On the Principles of mining which is valid for more than four decades has brought about significant changes in the Indonesia's economic development. But in its development Act No. 11 of 1967 material cargo rated centralized so it is no longer appropriate to the situation and the future challenges.

Mining development must adapt to the changing strategic environment both nationally and internationally. A major challenge faced by petambangan mineral and coal is the impact of globalization which encourages democratization, decentralization, human rights, the environment, technological developments, and information, as well as intellectual property rights and increase public prosecution. For the environmental challenges facing strategic and answer the problems it has drafted new legislation in lieu of Act No. 11 of 1967 on the Principles of Mining by Act No. 4 of 2009 on Mineral and Batubara.Sebelum the enactment of Act No. 4 in 2009, "The international agreements, both bilateral, regional and multilateral cooperation in the field of investment that has been approved by the Indonesian government before this law goes into effect, remain valid until the expiry of the agreements"

It is intended that all contracts made in the operations of extractive (mining) which is based on Article 8 UndangNomor Act 1 of 1967 concerning Foreign Investment, remain binding for the parties concerned. Article 8 of Act No. 1 of 1967 states that: "Foreign investment in the field of mining is based on a partnership with the Government on the basis of the contract / order form in accordance with the applicable legislation"

It is intended also to attract investors to invest in Indonesia.Namun after the enactment of Act No. 4 of 2009 mining activities based on the work contract changes that became permission law. The system is a step forward because the government mining contract system work has brought many losses to the nation and the people of Indonesia, because only cling to the principle of contract freedom. But, this legislation could make foreign investors fret the mining sector as well as lead to controversy and legal uncertainty. Because on the one hand the contents of the contract binding the parties to the contract but on the other hand must not violate the provisions of the legislation. Based on the background described above, the issues to be discussed in the writing of this study are: How Certainty Mining Investment Law According to provisions of Act No. 4 of 2009 on Mineral and Coal and Act No. 25 of 2007 on Investment?

\section{Results and Discussion}

\subsection{Mining Investment According to provisions of Act No. 11 of 1967 JunctoAct No. 4 of 2009}

In the mining business in the provisions of Act No. 11 of 1967 on the Principles of Mining

\footnotetext{
${ }^{4}$ Ibid., p.114

${ }^{5}$ Act No.25 of 2007 on Investment Cooperative Employees Pecanderan BKPM Jakarta 2007 Article 35.
} 
Terms based on the definitions and provisions of the agreement contained in the Civil Code. The agreement contained in the book III of the Civil Code. Book III of the Civil Code adheres to the principle of an open system, which means that the parties are free to contract with whomever define requirements, implementation as well as a written form of the contract either orally. This is known as the principle of freedom of contract referred to in paragraph 1 of Article 1338 Civil Code, which states that all contracts or agreements made are valid and enforceable as law for those who make it.

The principle of freedom of contract is then used as guidelines by the government and foreign investors, especially investors in the field of mining in accordance with the provisions of Act No. 11 of 1967 and the system that applies is the contract system. Thus the position of the parties to the contract are pemeritah premises of foreign investors is: An agreement by both parties; The position of the government, as businesses are aligned with investors; The procedure is a negotiation; It is two parties; Legal form of the agreement; If there is a dispute through arbitration or mediation process;

Legality exploitation of minerals statutory number number 4 of 2009 substantially only in a form that permit, in contrast to the legality of the concession at the time of the enactment of Act No. 1 of 1967, consists of a wide variety of forms namely Mining Authority (KP) contract work (KK), mineral and agreements coal mining works (PKP2B) and SIPDs for extractive industry and artisanal mining licenses for artisanal mining. Various legality at the time of the enactment of Act No. 11 of 1967, led to the coordination, supervision and control of less than the maximum, because every legality issued to a mining business activity carried out not in a good coordination. ${ }^{6}$

Departing from the weakness of the management and exploitation of minerals in the past, the Act No. 4 of 2009 on mineral and coal mining current provides guidance that the management and exploitation of minerals is carried out systematically since the establishment of the mining area, which is part of the spatial national. The implementation process of mining or territory zoning special mining and artisanal mining area, carried out by a mechanism that is transparent and accountable, by involving all elements of the central government or local governments, Parliament or the legislature and the public.

The utilization of minerals that have been directed legally by Act No. 4 of 2009, ranging from zoning-mining region, is expected to be a positive influence on the management and exploitation of minerals in the future, so that one side can reduce the problems that had occurred and the side others can encourage positive impacts as follows:

- Encourage the growth and development of mining activities, both foreign investment, and local;

- Encourage local community participation passion;

- Encourage the passion of local people to co-manage and exploit existing minerals, which opens opportunities through WPR-IPR facilities;

- Encouraging passion support activities and local economic growth;

- Increasing income countries / regions;

- The opening of new jobs;

- Pressing the negative impact of environmental damage, which has occurred due to

\footnotetext{
${ }^{6}$ Nandang Sudrajat op.cit p.65
} 
the diversity of the legality of mining activities, which led to mutual accusations between levels of government authority that often occurs;

Act No. 4 of 2009 on mineral and rock mining in the investment system implementation change is becoming a permit system as a way to both domestic invest domestic capital. The investment system into a system of contracts into the permit system is a radical step taken by the government due principally to make a change in position between the government and investors. If the contract system between the government and investors' position is the same position then the government changed the licensing system to be higher than investors in which the government acts only as a notch regulator.Perubahan is presumably not much to attract foreign investors to invest in Indonesia.

Horikawa Shuji, one of the Japanese entrepreneurs explain investment considerations as the water flow. Water always flows from the highest point to the lowest place. As for his boss, businesses are always looking for it, because that entrepreneurs need peace effort, hoping to get an adequate incentive in which he invests and get growth opportunities with its partners well. Without it, it is difficult for businesses to thrive. What can make investors feel at ease in doing is legal uncertainty, because the legal certainty investors can make some predictions about the business plan is doing. ${ }^{7}$

Thus, in addition to political factors and political economy, other factors into consideration for investors to invest is a matter of legal certainty and predictability. A similar opinion was expressed by Paul V. Horn. And Henry Gomez as follows:

"In making foreign investment a number of important points are to be taken into consideration. The investor is concerned, first, witn the safety of his investment and, second, with the return of the which it yields. The factors having a direct lie on Reviews These considerations may be classified as follows: (1). Political stability and financial integrity in the borrowing or the host country; (2) The purpose for the which the investment is made; (3) laws pertaining to capital and taxation, attitude towards foreign investment, and otheraspects of the investment climate of the host country; (4) future potential and economic growth of the country where the investment is made; (5) exchange-restrictions pertaining to the remission of profits and with-drawal of the initial investment."

Low skill labor, regulation of the employment field, and a number of problems related to the decentralized authority on the level of government investment. As far to say that the Government of Indonesia has made some considerable reform efforts by adopting a more strategic fiscal reform, trade liberalization, financial reformasisektor, taxation, employment and business regulatory reform. But the problem is a gap (gap) will antarapolitical Government to implementation in the field, including between regulation with reality application. Further said that the Government of Indonesia has made some considerable reform efforts by adopting a more strategic fiscal reform, trade liberalization, financial reformasisektor, taxation, labor, and business regulatory reform. But the problem is a gap will antarapolitical Government to implementation in the field, including adanyagap between regulation with reality application. Further said that the Government of Indonesia has made some considerable reform efforts by adopting a

\footnotetext{
${ }^{7}$ Mahmul Siregar Kepastian Hukum dalam Transaksi Bisnis Internasional dan Implikasinya Terhadap kegiatan Investasi di Indonesia Jurnal Hukum Bisnis Vol.27-4- 2008
} 
more strategic fiscal reform, trade liberalization, financial reformation, taxation, labor, and business regulatory reform. But the problem is a gap will antarapolitical Government to implementation in the field, including adanyagap between regulation with reality application.

In relation to mining activities in the provisions of Act No. 11 of 1967 on the basis of actual work contract system has given rise to legal uncertainty for the Indonesian government. contract system makes the government as a regulator or as businesses will only weaken the position of the government for one side to make regulations as well as businesses that must obey the rule of law. It will carry the implication that if there is a dispute in the future and if brought to international arbitration after defeats, then the country's assets that will be at stake. So that the terms of the contract that turned into a permit is one step forward to restore its position as a regulator and also to enhance national development,

The existence of Act No. 4 of 2009 in economic development especially in the mining sector say quite aspirational for cargo material more responsive. Substantially there are fundamental differences between the Act No. 11 of 1967 by Act No. 4 of 2009. Due in Act No. 4 of 2009 is considered pretty good cargo including, among others:

- Auction extractive potential region. The rule about the auction area potentially containing minerals. Any company or party to the husbandry, mineral or coal metals in particular should be through an auction process. This method is viewed as an advance in the business world national mining.

- More accommodating, ie with the entry rules more aligned to the interests of the people, compared with provisions of the Mining Act No. 11 of 1967.

- A strategic technical considerations excavated material is determined based on the national interest and not on the type of minerals. That is, if an extractive technically, economically, interests, and in terms of defense and security of the state / government.

- The existence of a clear division of authority between the management of each level of government.

- The existence of an integrated management, from exploration through mine closure handling.

In Act No. 4 of 2009 as the points above it is clear that the regional government is given a greater role in carrying out development in managing mining operations in their respective regions.

The establishment of Act No. 4 Of 2009 on Mineral and Coal Mining is a consequence of the enactment of Act No. 32 Of 2004 on Regional Government and Act No. 33 of 2004 on Financial Balance between Central Government and Local Government which has given very broad authority for local governments which have given very broad authority for local governments in the field of mining as stipulated in Government Regulation No. 25 Of 2000 on Government Authority and Provincial Autonomous Regions. In addition to the above-mentioned background, the background of another establishment Act No. 4 of 2009 is to encourage democratization, decentralization, human rights, environment, development of technology and information, ${ }^{8}$

\footnotetext{
${ }^{8}$ General Explanation of Act No. 4 of 2009 Paragraph 3
} 
Act No. 4 of 2009 contains the main points pkiran as follows:

- Mineral and coal as nonrenewable resources controlled by the State and the development and pendayagunaannya implemented by the Government and the local government together with businesses.

- The government subsequently provides the opportunity to entities incorporated in Indonesia, Cooperative, Individual, and the local community remedy has exploited the mineral and coal based license, which is in line with regional autonomy, granted by the Government and / or Regional Government in accordance with their respective authorities.

- In the framework of the implementation of decentralization and regional autonomy, management of mineral and coal carried out based on the principle of externality, accountability, and efficiency involving the Government and Local Government;

- Mining should provide economic and social benefits for the welfare of the people of Indonesia;

- Mining should be able to accelerate the development of the region and encourage economic activity in the community / small and medium-sized businesses as well as encourage the emergence of supporting mining industry;

- In order to establish sustainable development, mining activities should be carried out with due regard to environmental principles, transparency and public participation. ${ }^{9}$

In Act No. 11 of 1967 there is a difference is if the investors in the country then the form is mining authorization (KP), while the foreign investor is then shaped work contracts and agreements for mineral mining coal mining works (PKP2B). While in Act No. 4 of 2009 is no distinction that only the Mining Business License (IUP) .Ketentuan also refers to Act No. 25 of 2007 on the Capital planting.

\subsection{Mining investment according to the provisions of Act No. 25 of 2007 on investment}

Prior to the issuance of Act No. 25 of 2007 is still a very significant difference between foreign investors and investors in this state. The thing seen from the provisions of the legislation which regulating. Foreign investment is regulated in Act No. 1 of 1967 concerning Foreign Investment whereas domestic investment stipulated in Act No. 6 of 1968 on Domestic Investment. With the enactment of Act No. 25 of 2007 so with the terms of their differences are united. So that legal certainty is more focused and clear in implementation. No difference between foreign investors and domestic investors.

Rights, obligations and responsibilities of investors is specifically regulated in order to provide legal certainty, reinforce investor obligations towards the implementation of the principles of sound corporate governance, giving tribute to the cultural traditions of the community, and implement social responsibility of factory. Regulated responsibility of investors needed to encourage a climate of healthy competition, increase environmental responsibility and fulfill the rights and obligations of workers, as well as efforts to encourage adherence to investors on regulations. Right, Duties, and responsibilities of investors in these laws contained in the Compilation of chapter as follows:

9 Ichigo Kenichi Sejarah Hukum Pertambangan Di Indonesia http://ichigokenichi.blogspot.com/2011/10/sejarah-hukumpertambangan-diindonesia.html (Accessed on 15 June 2018) 
Article 14: Each investor is entitled to:

a) rights, law, and protection;

b) open information regarding business sector is running;

c) service rights; and

d) various forms of convenience facilities in accordance with the provisions of the legislation.

Article 15: Every investor is obliged to:

a) apply the principles of good corporate governance;

b) implementing corporate social responsibility;

c) a report on the investment activities and submit it to the Investment Coordinating Board;

d) respecting the cultural traditions of communities around the location of investment business activities; and

e) comply with all the provisions of the legislation.

Article 16: Every investor is responsible:

a) guarantee the availability of capital from sources that do not conflict with the provisions of laws and regulations;

b) bear and settle all liabilities and losses if investors stop or leave or abandon unilaterally its business activities in accordance with the provisions of the legislation;

c) create a business climate of fair competition, prevent monopoly practices, and other things that hurt the country;

d) preserving the environment;

e) promotion of safety, health, comfort and welfare; and

f) comply with all the provisions of the legislation.

Article 17: Investors exploiting natural resources that are not renewable gradually must allocate funds for the restoration of the location that meets the standards of environmental feasibility, the implementation of which is set in accordance with the provisions of the legislation.

In his explanation of Article 3Ayat (1) Letter explained that what is meant by "the principle of legal certainty" is a principle in law that put the state laws and the provisions of the legislation as the basis for every policy and action in the areas of further cultivation in the explanation capital letter. The investors will get the same treatment either foreign investors or investors in state. That meant by "the principle of equal treatment and did not distinguish the origin of the country" is the principle of nondiscriminatory treatment services based on the provisions of laws and regulations, both between domestic investors and foreign investors and between investors from the foreign countries and investors from other foreign countries.

These provisions will apply to all investment activities in Indonesia, including in the mining business, while still referring to Act No. 4 of 2009.

\section{Closing}

\subsection{Conclusion}

From the above explanation can be concluded then that is: 
- Legality exploitation of minerals statutory number number 4 of 2009 substantially only in a form that permit, in contrast to the legality of the concession at the time of the enactment of Act No. 1 of 1967, consists of a wide variety of forms namely Mining Authority (KP) contract work (KK), mineral and agreements coal mining works (PKP2B) and SIPDs for extractive industry and artisanal mining licenses for artisanal mining.

- Prior to the issuance of Act No. 25 of 2007 is still a very significant difference between foreign investors and domestic investors. This is evident from the provisions of legislation regulating. Foreign investment is regulated in Act No. 1 of 1967 concerning Foreign Investment whereas domestic investment stipulated in Act No. 6 of 1968 on Domestic Investment.

\subsection{Suggestion}

- The application of legal principles in this legislation also continue to promote forms of Alternative Dispute Resolution (ADR) through the courts or through the courts. The courts also can be divided again into the application of criminal law or the application of civil law. The application of civil law is done through compensation and environmental restoration, the ultimate responsibility, the right to sue the government and local government, legal standing and the right to sue public environmental organizations.

- With the enactment of Act No. 25 of 2007 so with the terms of their differences are united. So that legal certainty is more focused and clear in its implementation. There is no difference between foreign investors and domestic investors

\section{References}

[1] H.S. H.Salim 2010 Hukum Pertambangan Di Indonesia Sinar Grafika Jakarta

[2] Ilmar Amirudin 2004 Hukum Penanaman Modal Di Indonesia Penerbit Prenada Media Jakarta

[3] Sudrajat Nandang 2010 Teori dan Praktik Pertambangan Indonesia Menurut Hukum Pustaka Yustisia Yogyakarta

[4] Ichigo Kenichi Sejarah Hukum Pertambangan Di Indonesia http://ichigokenichi.blogspot.com/2011/10/sejarah-hukumpertambangan-diindonesia.html

[5] Yeti 2006 Dilema Pertambangan Freeport Dalam Dimensi Hukum Jurnal Hukum Vol.6 No.1 Tahun 2006

[6] Mahmul Siregar Kepastian Hukum dalam Transaksi Bisnis Internasional dan Implikasinya Terhadap kegiatan Investasi di Indonesia Jurnal Hukum Bisnis Vol.27No.4-Tahun 2008

[7] Act No. 4 of 2009 on Mineral and Coal and its explanation.

[8] Act No. 25 of 2007 on Investment

[9] Act No. 11 of 1967 About Conditions Principles of Mining 